\title{
Perilaku Masyarakat Pesisir di Hutan Mangrove Desa Balangdatu Kabupaten Takalar
}

\author{
Shermina Oruh ${ }^{1}$, Hasruddin Nur ${ }^{2}$ \\ ${ }^{1}$ Ilmu Pengetahuan Sosial, Universitas Pejuang Republik Indonesia, Indonesia \\ ${ }^{2} I l m u$ Pengetahuan Sosial, Universitas Sawerigading Makassar, Indonesia \\ Email:soruh@yahoo.fr
}

\begin{abstract}
Abstrak, Penelitian ini bertujuan untuk mengetahui (i) bentuk perilaku masyarakat pesisir di hutan mangrove. (ii) dampak dari perilaku masyarakat di hutan mangrove.Jenis penelitian yang digunakan deskriptif kualitatif.Penelitian ini bertujuan untuk menggambarkan perilaku masyarakat pesisir di hutan mangrove Desa Balangdatu dan dampak perilaku masyarakat pesisir di hutan mangrove Desa Balangdatu Kabupaten Takalar.Adapun teknik pengumpulan data yaitu dengan melakukan observasi, wawancara, dan dokumentasi. Teknik pengabsahan data yaitu triangulasi sumber yaitu untuk mengkaji kredibilitas data yang dilakukan dengan cara mengecek data yang telah di peroleh melalui beberapa sumber.Dari hasil penelitian ditemukan bahwa (i) Bentuk perilaku masyarakat pesisir dihutan mangrove terdiri dari perilaku ekosentrisme (melestarikan) dan perilaku antroposentrisme (merusak). Perilaku melestariakan terdiri atas pelesetarian berbasis masyarakat dan pelestarian hutan mangrove dengan penerapan kearifan lokal (local wisdom), sedangkan perilaku merusak masyarakat melakukan eksplotasi secara berlebihan, terjadi alih fungsi lahan mangrove menjadi tambak dan terjadi pencemaran lingkungan. (ii) Dampak perilaku masyarakat di hutan mangrove meliputi dampak positif dan dampak negatif yang berpengaruh terhadap fungsi ekonomi dan ekologi hutan mangrove.
\end{abstract}

Kata Kunci: Perilaku, Masyarakat, dan Hutan mangrove

\begin{abstract}
This study aims to determine (i) the forms of coastal community behavior in mangrove forests. And (ii) the impact of community behavior on mangrove forests. This type of research is descriptive qualitative. This study aims to describe the behavior of coastal communities in the mangrove forests of Balangdatu Village and the impact of the behavior of coastal communities in the mangrove forests of Balangdatu Village, Takalar Regency. The data collection techniques are by conducting observations, interviews, and documentation. The data validation technique is source triangulation, which is to examine the credibility of the data by checking the data that has been obtained through several sources. From the results of the study found that (i) The form of behavior of coastal mangrove forest community consists of ecocentrism (preserving) and anthropocentrism (damaging). Sustainable behavior consists of community-based conservation and preservation of mangrove forests with the application of local wisdom, while destructive behavior of the community over-exploits, changes the function of mangrove lands into ponds and environmental pollution. (ii) Impacts of community behavior in mangrove forests include positive and negative impacts that affect the economic and ecological functions of mangrove forests.
\end{abstract}

Keywords: Behavior, Community, and Mangrove Forest 


\section{PENDAHULUAN}

Wilayah pesisir merupakan daerah peralihan laut dan daratan yang kaya akan sumber daya alam yang banyak dimanfaatkan oleh masyarakat sekitarnya. Selain sebagai tempat untuk memenuhi kebutuhan sehari-hari, masyarakat juga memanfaatkan pesisir sebagai kawasan wisata dan perikanan.Hal tersebut menyebabkan wilayah pesisir mendapat tekanan didarat maupun dilaut.Begitu pula dengan hutan mangrove, hutan yang memiliki peran penting bagi wilayah pesisir.Hutan mangrove atau dikenal dengan hutan bakau adalah hutan yang tumbuh di air payau serta terletak pada garis pantai yang dipengaruhi oleh pasang surut air laut.

Hutan mangrove sudah menjadi bagian yang tidak terpisahkan bagi kehidupan masyarakat pesisir yang dimanfaatkan sebagai pelindung dan sumber pendapatan.Oleh karena itu keberadaan hutan mangrove harus dijaga dan dilestarikan.Kelestarian hutan mangrove tidak terlepas dari perilaku masyarakat yang ada disekitar.Perilaku merupakan respon atau reaksi seseorang karena mendapat rangsangan dari lingkungan.Adanya perilaku dan aktifitas masyarakat di hutan mangrove merupakan salah satu faktor penyebab terjadinya kerusakan.

Secara umum, hutan mangrove memiliki peranan penting dalam melindungi daratan dari hempasan gelombang air laut.Selain itu hutan mangrove dijadikan habitat dan kawasan perkembangbiakan bagi ikan, udang dan kepiting.Hutan mangrove memiliki peranan yang penting bagi lingkungan hidup, oleh karena itu hutan mangrove harus dijaga dan dilestarikan.

Namun tidak dapat dipungkiri bahwa, setiap perilaku masyarakat berpengaruh terhadap lingkungan dimana setiap manusia memiliki perilaku yang berbeda-bede tergantung dari bagaimana manusia atau individu itu berinteraksi dengan lingkungannya.

\section{TINJAUAN PUSTAKA}

a. Perilaku Sosial

Menurut B.F Skinner dalam Mustaqim (2016) mengatalan bahwa paradigma perilaku sosial memusatkan perhatiannya kepada hubungan antara individu dan ingkungannya yang terdiri atas bermacam-macam objek sosial dan non sosial yang menghasilkan akibat-akibat atau perubahan dalamfaktor lingkungan yang menimbulkan perubahan terhadap terhadap tingkah laku.Oleh karena itu perilaku terjadi karna adanya stimulus terhadap organisme dan kemudian organisme merespon, maka teori Skinner disebut teori "S-O-R".Kemudian perilaku sosial juga merupakan suatubentuk tanggapan atau reaksi individu yang terwujud dalam gerakan atau sikap dan ucapan.Semua manusia dalam bertingkah laku pada dasarnya dimotivasi oleh kebutuhan yang saling berkaitan satu sama lain sebagai wujud dari adanya tuntutan dalam hidup. (Pramudji,2000)

Jadi dapat disimpulkan bahwaperilaku sosial adalah perilaku yang dilakukan oleh individu dalam masyarakat, yang pada dasarnya sebagai respons terhadap lingkungannya.Perilaku manusia tidak lepas dari keadaan individu itu sendiri dan lingkungan dimana individu itu berada.Adanya perilaku masyarakat di hutan mangrove terjadi dalam rangka memenuhi kebutuhan hidup.Perilaku masyarakat masyarakat sangat dipengaruhi oleh alam.Alam memberikan apapun yang masyarakat butuhkan dari tempat tinggal sampai kebutuhan untuk bernafas.Namun kini masyarakat sudah menunjukan ciri modernnya yakni masyarakat yang mulai menunjukan tanda yang berbeda dari masyarakat sebelumnya, sebuah masyarakat yang berproses menuju kemajuan disertai pola pikir yang rasional dan kompetitif. Oleh karena itu Rahmad K.Dwi Susilo (2014) membedakan perilaku masyarakat menjadi dua macam yaitu: a. Perilaku Ekosentrisme, perilaku ini muncul dalam bentuk pengerusakan, pencemaran, eksploitasi dan lain-lain. b. Perilaku antroposentrisme, perilaku ekosentrisme perilaku ini muncul sebagai tindakan pelestarian, penghijauan dan penanaman, dan perawatan alam.

\section{b. Konsep Masyarakat Pesisir}

Menurut Paul.B.Horton mengatakan bahwa masyarakat adalah sekumpulan manusia yang relative mandiri, hidup bersama cukup lama, mendiami wilayah tertentu memiliki 
kebudayaan yang sama dan melakukan sebagian besar kegiatan kelompok pertanian (Gumilar,2018:145). Sedangkan Menurut Undang-undang (UU) Nomor 27 Tahun 2007 pasal 1 bahwa pesisir adalah daerah peralihan antara ekosistem darat dan laut yang dipengaruhi oleh perubahan didarat maupun dilaut.

Berdasarkan pengertian diatas maka dapat disimpulkan bahwa masyarakat pesisir adalah sekolompok warga yang tinggal di wilayah pesisir yang hidup bersama dan memenuhi kebutuhan hidupnya dari sumber daya yang ada dipesisir.Salah satu kekayan pesisir yang banyak dimanfaatkan adalah hutan mangrove.

c. Akses Masyarakat di Hutan Mangrove

Kata Mangrove berasal dari kata Mangue (bahasa Portugis) yang berarti tumbuhan, dengan Grove (bahasa Inggris) belukar. Sementara itu dalam literature lain disebutkan bahwa mangrove berasal dari bahasa Melayu disebut mangi-mangi (Hardhani,2002). Jadi dapat disimpulkan bahwa hutan mangrove merupakan hutan yang tumbuh di air payau dan dipengaruhi oleh pasang surut air laut.

Akses hutan mangrove disini lebih luas dibandingkan hutan lindung lainnya dimana masyarakat bebas mengambil mangrove sesukanya bahkan adanya persepsi masyarakat bahwa lahan mangrove merupakan aset milik masyarakat sehingga mereka berhak mengelola hutan mangrove.Timbulnya persepsi tersebut erat kaitannya dengan kepentingan masyarakat untuk memiliki akses terhadap sumber daya hutan mangrove sebagai sumber matapencaharian, terkadang masyarakat dalam memanfaatkan hutan mangrove sebagai sumber pendapatan cenderung merusak.Bertolak dari sejarah terjadinya degradasi hutan mangrove di Pulau Tanakeke yang terjadi akibat sumberdaya alam di wilayah ini bisa diakses oleh semua warga masyarakat(open acces).

d. Landasan Teori

Peluso dan Ribot (2003) mendefenisikan akses sebagai suatu kemampuan untuk menghasilkan sesuatu termaksud diantaranya objek material, perorangan, institusi, dan simbol.Dengan memfokuskan pada kemampuan dibandingkan kepemilikan.Peluso dan Ribot melihat bahwa ada susunan jaringan akses dimana akses disini ditempatkan pada analisa siapa sebenarnya beruntung terhadap sesuatu dan melalui proses apa yang mereka lakukan. Akses memfokuskan diri pada siapa yang mendapatkan apa, dalam cara apa, dan kapan.
Mekanisme akses terdiri atas akses legal dan akses illegal.

Dalam konteks ini hutan mangrove di jadikan akses oleh pihak-pihak tertentu untuk mendapatkan keuntungan dimana akses disini berfokus pada perilaku yang dilakukan seseorang untuk mendapatkan sesuatu dalam memenuhi kebutuhan ekonomi. Karena akses itu terkait dengan kekuasaan maka masyarakat bebas memanfaat hutan mangrove karena adanya status kepemilikan didalam masyarakat, akan tetapi meskipun demikian apabila masyarakat tidak memiliki modal maka mereka tidak dapat menikmati sumberdaya hutan mangrove.

Adanya akses masyarakat dihutan mangrove menjadi pemicu terbentuknya perilaku masyarakat terhadap keberadaan mangrove yaitu perilaku melestarikan dan perilaku merusak.Meningkatnya kebutuhan ekonomi masyarakat pesisir mendorong masyarakat untuk bersaing mendapatkan akses sumber kehidupan mereka.

\section{METODE}

Penelitian ini menggunakan metode penelitian kualitatif sebagai produser penelitian untuk mendapatkan data deskriptif yaitu sebuah penelitian yang berusaha memberikan gambaran umum mengenai objek yang diamati atau diteliti mengenai fakta yang ada dilapangan tentang perilaku masyarakat pesisir di hutan mangrove Desa Balangdatu Kabupaten Takalar..

Adapun lokasi dalam penelitian ini di Desa Balangdatu Kepulaun Tanakeke karena perilaku masyarakat pesisir di hutan mangrove ini telah terjadi dari sejak tahun 1980 an ditandai dengan degradasi hutana mangrove.

Sasaran penelitian informan dalam penelitian ini adalah masyarakat pesisir yang memanfaatkan hutan mangrove untuk memenuhi kebutuhan ekonomi.Pemilihan informan dalam penelitian ini menggunakan cara purposive sampling atau pengambilan data yaitu menentukan kriteria informan yakni masyarakat yang berdomisi di Desa Balangdatu dan masyarakat multi pekerja.

Dalam penelitian ini mengungkap perilaku masyarakat pesisir di hutan mangrove Desa Balangdatu Kabupaten Takalar yang dirumuskan oleh peneliti.Dalam penelitian ini instrument utama adalah peneliti sendiri, yang diketahui oleh subjek atau informan.Adapun alat yang digunakan oleh peneliti yaitu berupa alat 
tulis, pedoman wawancara, kamera, dan alat perekam.

Jenis data yang digunakan dalam penelitian ini adalah jenis data primer dan sekunder. Data primer dalam penelitian ini adalah hasil observasi dan wawancara dengan informan penelitian yaitu perilaku masyarakat dalam memanfaatkan hutan mangrov. Data sekunder adalah data yang sudah tersedia dan diperoleh peneliti dari pihak narasumber.Sumber informan dalam penelititan ini terbagi menjadi 3 (tiga) yaitu sebagai berikut:(1) Informan kunci yaitu informan yang bisa membukakan pintu untuk mengenali keseluruhan medan secara luas, dalam hal ini masyarakat pesisir.(2)Informan ahli, yaitu informan yang terlibat secara langsung dalam suatu kegiatan atau interaksi, dalam hal ini masyarakat yang melestariakn dan merusak mangrove.(3) Informan biasa, yaitu informan yang mengetahui suatu program atau kegiatan namun ia tidak berpartisipasi langsung dalam program tersebut.

Adapun teknik pengumpulan data yang digunakan dalam penelitian ini adalah: Wawancara Mendalam, Observasi dan dokumentasi.

Teknik wawancara yang dilakukan adalah dengan melakukan tanya jawab langsung kepada informan yang berdasarkan pada tujuan penelitian. Teknik wawancara yang dilakukan penulis adalah dengan cara mencatat berdasarkan pedoman pada daftar pertanyaan yang telah di siapkan sebelumnya.

Dengan melakukan pengamatan dan pencatatan secara langsung terhadap hal yang di anggap berhubungan dengan objek yang diteliti, atau hal yang berkaitan dengan masalah penelitian.

Dokumentasi yang di maksudkan penulis disini adalah peninggalan tertulis seperti arsip-arsip dan termasuk juga buku, teori, dalil atau hukum-hukum, dan lain-lain yang termasuk dengan masalah penelitian.

Data yang diperoleh dari hasil penelitian akan dianalisis secara kualitatif, data yang diperoleh di lapangan, diolah kemudian disajikan dalam bentuk tulisan. Dalam peneitian ini proses analisis data yang digunakan adalah sebagai berikut : (1) Reduksi data, peneliti menyaring data yang diperoleh pada saat melakukan penelitian, baik itu pada saat wawancara dengan masyarakat desa Balangdatu, masyarakat yang melestarikan dan menebang hutan mangrove; (2) Penyajian data, peneliti menyajikan data secara keseluruhan dari hasil penelitian; (3) Kesimpulan, merupakan proses untuk menjawab permasalahan dan tujuan penelitian yakni perilaku masyarakat pesisir di Desa Balangdatu kabupaten Takalar.

\section{HASIL DAN PEMBAHASAN}

\section{1) Bentuk Perilaku Masyarakat Pesisir di Hutan Mangrove Desa Balangdatu Kabupaten Takalar}

Perilaku

(pelestaraian).Ekosentrisme ialah sikap perjuangan menyelamatkan dan keperdulian terhadap lingkungan yang tidak hanya mengutamakan penghormatan atas spesies tapi perhatian setara atas seluruh kehidupan.Dalam masyarakat, sikap ini muncul sebagai tindakan pelestarian, penghijauan dan penanaman, dan perawatan alam. Demikian dengan hutan mangrove, dimana hutan mangrove merupakan ekosistem yang sangat komplek juga memiliki sumberdaya alam yang sangat potensial. Sehingga hutan mangrove juga sangat menjanjikan untuk dikonversi menjadi berbagai kegiatan yang sangat menguntungkan, khususnya usaha tambak ikan dan udang.

Jika dilihat dari peran serta masyarakat dalam penelitian menunjukkan bahwa masyarakat ikut terlibat dalam melestarikan hutan mangrove. Sebagaimana yang dikatakan oleh salah satu narasumber yang namanya disingkat DR (51 tahun) pada saat wawancara :"salah satu yang dilakukan amsyarakat dan kelompok tani/komunitas ini untuk tetap melestarikan hutan mangrove dengan melakukan upaya rehabilitasi kawasan mangrove dengan melibatkan peran serta masyarakat melalui kegiatan pembibitan, penanaman, dan penjagaan." (wawancara, 18 Januari 2020)

Dari pernyataan diatas yang disampaikan, dapat disimpulkan bahwa pada proses pelestarian hutan mangrove di Desa Balangdatu dilakukan masyarakat, pemerintah setempat maupun komunitas yang ada di Desa dengan melakukan penyuluhan tentang hutan mangrove dalam rangka memberi informasi kepada masyarakat terhadap pentingnya kelestarian hutan mangrove bagi lingkungan hidup kemudian melibatkan masyarakat dalam proses pembibitan, penanaman dan penjagaan terhadap mangrove. Dengan tindakan selanjutkan dimana masyarakat memiliki peranan penting dalam 
memperhatikan mangrove tersebut agar selalu terjaga. Bentuk perilaku melestarikan mangrove ini dilakukan dengan cara pengelolaan berbasis masyarakat dimana mengandung arti keterlibatan langsung masyarakat dalam mengelola sumber daya alam dengan menjadikan masyarakat sebagai pelaku utama. Oleh karena itu, pandangan masyarakat mengenai keberadaan hutan mangrove perlu diarahkan kepada cara pandang tentang betapa pentingnya pelestarian sumberdaya hutan mangrove tersebut.

Selain melestarikan hutan mangrove dengan pengelolaan berbasis masyarakat, bentuk perilaku melestarikan lainnya yaitu dengan membuat sebuah aturan-aturan yang mengikat masyarakat dalam mengakses hutan mangrove. Aturan-aturan tersebut dalam bentuk penerapan kearifan lokal. Kearifan lokal ini mengatur bagaimana tata cara penebangan mangrove walaupun dilahan milik pribadi tetap harus menyusaikan aturan. Sebagaimana yang dikatakan oleh H.P (67 tahun) pada saat wawancara bahwa : "untuk menjaga kelestarian hutan mangrove maka masyarakat bersama perangkat desa lainnya melakukan perundingan, sehingga lahirlah aturan-aturan dalam memanfaatkan hutan mangrove seperti setiap penebangan mulai dari $4 \mathrm{~m}$ diwajibkan untuk menyisahkan 1 pohon induk. Hal ini dibuat agar perkembangan mangrove tetap berlangsung dengan harapan pohon induk akan berkembang dan calon mangrove baru bisa tumbuh." (Wawancara tanggal 19 Februari 2020)

Dari pernyataan diatas yang disampaikan, dapat disimpulkan bahwa bentuk perilaku masyarakat dalam melestarikan hutan mangrove tidak hanya dalam pengelolan berbasis masyarakat tetapi berupa aturan-aturan tidak tertulis yang bertujuan mengatur perilaku masyarakat dalam memanfaatkan hutan mangrove.Jadi, masyarakat tidak semerta-merta melakukan eksploitasi di hutan mangrove, bahkan masyarakat tidak menebang hutan mangrove secara liar tapi harus sesuai aturan yang telah disepakati bersama.Aturan tersebut dalam bentuk atura tidak tertulis tapi bersifat mengikat.

Perilaku antroposentrisme (merusak). Antroposentrisme menyatakan bahwa, tumbuhan disediakan untuk hewan dan hewan disediakan untuk manusia selain itu manusia lebih terhormat karena selain memiliki badan manusia juga memiliki jiwa yang memungkinkan untuk berfikir.Sehingga manusia dipandang sebagai pihak yang memiliki kebebasan untuk menterjamahkan kepentingannya terhadap alam.Dalam kenyataan sikap ini muncul dalam bentuk pengrusakan, pencemaran, eksploitasi dan lain-lain.

Berbagai masalah lingkungan berkaitan dengan pengetahuan, sikap, perilaku dan penilaian manusia terhadap lingkungan serta kurangnya kesadaran dan pemahaman masyarakat tentang manfaat yang diperoleh dari hutan mangrove dan tekanan biaya hidup menyebabkan masyarakat pesisir sering melakukan perusakan di lingkungan pesisir. Sebagaimana yang dikatakan RL (28 tahun) pada saat wawancara bahwa :"masyarakat Desa Balangdatu memiliki tingkat ketergantung sangat tinggi pada bakau/mangrove dalam menopang kehidupan ekonominya. Tingginya ketergantungan tersebut menyebabkan tingkat eksploitasi mangrove, seperti penebangan hutan mangrove untuk dijadikan kayu bakar dan arang."(wawancara 20 Februari 2020)

Dari pernyataan diatas yang disampaikan dapat disimpulkan bahwa masyarakat melakukan eksplotasi di hutan mangrove karena kepentingan ekonomi seperti meningkatnya konversi lahan tambak karena usaha tambak memberikan peluang pendapatan lebih baik bagi masyarakat yang tinggal di wilayah pesisir. Selain itu dorongan kebutuhan hidup/ekonomi mereka yang semakin meningkat mendorong masyarakat tidak menghiraukan lagi kelestarian lingkungan. Sebagai contoh untuk kebutuhan akan bahan bakar dimana mereka mulai merambah hutan tanaman mangrove karena harga bahan bakar minyak/bahan bakar lainnya yang semakin mahal dan langka. Kondisi seperti ini merupakan ancaman bagi keberlanjutan lingkungan hutan mangrove.

\section{b) Dampak Perilaku Masyarakat Pesisir di Hutan Mangrove Desa Balangdatu Kabupaten Takalar}

Dampak Posisif perilaku masyarakat di Hutan mangrove.Dampak positifadalah suatu keadaan atau hasil dari suatu perilaku atau tindakan yang bernilai positif.Bila disorot dari segi ekonomis, hutan mangrove sekaligus merupakan kawasan wisata yang menarik di daerah pesisir dan merupakan tempat perbenihan ikan, udang dan kepiting, mangrovejuga dapat menghasilkan berbagai produk kayu dan nonkayu. Sebagaimana yang dikatakan DS (48 tahun) pada saat wawancara bahwa :" Mangrove lebih banyak memiliki dampak positif dimana masyarakat desa Balangdatu menggunakan 
hutan mangrove sebagai salah satu penopang perekonoman mereka. Manfaat langsung yang dirasakan oleh masyarakat oleh masyarakat setempat meliputi hasil kayunya seperti kayu bakar, arang, dan untuk patok rumput laut.Selain itu mangrove jenis rhizopora mucronata sp dapat di jadikan tanaman obat" (wawancara 1 Februari 2020).

Dari pernyataan diatas yang disampaikan dapat disimpulkan bahwamasyarakat memanfaatkan mangrove untuk memenuhi kebutuhannya dan meningkatkan ekonomi keluarganya seperti mencari ikan, udang, dan kepiting selain untuk dikonsumsi hewan tersebut dapat dipasarkan .Selain itu dengan adanya hutan mangrove dapat melindungi pemukiman masyarakat dari terjangan ombak dan abrasi.Selain itu, mangrove jenis rhizopora dapat dijadikan obat untuk menyembuhkan penyakit tertentu.

Dampak negatif perilaku masyarakat di Hutan mangrove.Dampak negatifadalahsuatu keadaan atau hasil dari suatu perilaku atau tindakan yang bernilai negatif.Masyarakat desa Balang Datu dominan memanfaatkan hutan mangrove sebagai tempat untuk memenuhi kebutuhan dan meningkatkan ekonomi keluarga.Seperti degan yang dikatakan oleh salah seorang informan yang bernama BR (37 tahunbahwa :"kerusakan pada mangrove dapat mempengaruhi kehidupan ekonomi masyarakat pesisir, seperti penurunan hasil tangkapan ikan dan berkurangnya pendapatan nelayan. Selain itu, juga dapat merusak habitat spesies ikan, dan biota laut yang hidup di dalamnya, serta abrasi pantai. Dulu pada tahun 1970 an ketika hutan mangrove masih lebat banyak sekali jenis ikan dijumpai seperti kerapu, kakap merah, ikan gulama. Tetapi sekarang ikan tersebut sudah jarang dijumpai karena pindah ketempat lain." (wawancara, 15 Februari 2020)

Dari pernyataan diatas yang disampaikan dapat disimpulkan bahwa apabila masyarakat sadar akan fungsi hutan mangrove, pasti kita akan berpikir dua kali untuk merusaknya. Fungsi yang sangat penting dari adanya hutan mangrove untuk menjaga abrasi pantai, untuk mengurangi kuatnya arus laut yang menghantam bibir pantai atau wilayah pesisir pada umumnya. Tidak hanya itu, dengan adanya mangrove dapat menambah penghasilan masyarakat dengan mencaribiota laut untuk di konsumsi bahkan untuk dijual kemasyarakat sekitar.

\section{Pembahasan}

\section{1) Bentuk Perilaku Masyarakat di Hutan Mangrove Desa Balangdatu Kabupaten Takalar}

Sumberdaya yang berada di daerah pesisir dan laut merupakan salah satu potensi ekonomi yang sangat menjanjikan dalam menopang kehidupan masyarakat pulau, khususnya masyarakat nelayan.Pemanfaatan sumberdaya di wilayah pesisir semakin pesat seiring dengan semakin tingginya kebutuhan masyarakat.Salah satu pemanfaatan sumberdaya di pesisir yang paling banyak dimanfaatkan adalah hutan mangrove.Oleh karena itu, banyak masyarakat yang memanfaatkan hutan mangrove untuk meningkatkan kesejahteraannya.Adanya ketergantungan tersebut menentukan perilaku masyarakat terhadap keberadaan hutan mangrove di Desa Balangdatu Kabupaten Takalar. Berdasarkan hasil pengamatan langsung di lapangan, mayoritas masyarakat memiliki lebih dari satu pekerjaan, akan tetapi pada umumnya mayoritas utama adalah nelayan, petani rumput laut, dan petambak.

a. Perilaku Ekosentrisme (Melestarikan)

Bentuk perilaku masyarakat erat kaitannya dengan akses yang dimiliki masyarakat terhadap hutan mangrove.Kepemilikan lahan mangrove di Desa Balangdatu sebagian berasal dari aset keluarga yang diwariskan secara turun temurun dan sebagian berasal dari hasil pembelian. Berkaitan dengan akses, dimana Ribot dan Peluso (2003) mengatakan bahwa, karena akses itu terkait dengan kekuasaan (power) maka masyarakat bebas memanfaatkan hutan mangrove karena adanya status kepemilikan sehingga sumber kekuasaan yang diperoleh beranekaragam seperti akses pada teknologi,pasar, tenaga kerja, pengetahuan, akses yang diperoleh dari negosiasi dengan relasi sosial merupakan sumber-sumber kekuasaan yang memungkin seseorang atau kelompok masyarakat dapat mengakses sumberdaya.

Perilaku manusia pada dasarnya terjadi sebagai tanggapan terhadap stimulus yang berasal dari lingkungan diluar diri manusia. Tanggapan terhadap stimulus yang berasal dari lingkungan tersebut akan menentukan perilaku indivudi sebagai reaksi terhadap stimulus yang sama. Bercermin pada peristiwa terjadinya degradasi hutan mangrove dan dampak negatif yang ditimbulkan maka masyarakat Desa 
Balangdatu mulai menyadari akan pentingnya untuk mengelola hutan mangrove.

Dalam pelestarian hutan mangrove di Desa Balangdatu terdapat upaya-upaya yang dilakukan yaitu pelestarian berbasis masyarakat dan pelestarian dengan penerapan kearifan lokal.Pelestarian berbasis masyarakat meliputi pembimbitan dimana pembuatan bibit tanaman mangrove dilakukan dilahan masing-masing baik secara perorangan maupun kelompok.Penanaman, penanaman biasanya dilakukan secara bersama-sama, mulai dari pembersihan lahan, pemasangan ajir (patok), dan pengangkutan bibit sampai pada penanaman di lokasi yang telah ditentukan. Selain itu, kegiatan ini mempererat rasa persaudaraan dan kebersamaan antara sesama masyarakat dan pada saat-saat tertentu melibatkan lingkungan pendidikan sebagai pendidikan lingkungan usia dini. Kemudian pemeliharan dan pengawasandilakukan oleh masyarakat sekitar terhadap keadaan tanaman yang baru di tanam agar tidak rusak atau mati akibat terkena hempasan ombak yang kuat.

Kemudian, pelestarian dengan penerapan kearifan lokal.Kearifan lokal ini mengatur bagaimana tata cara penebangan mangrove walaupun dilahan milik pribadi tetap harus menyusaikan aturan. Setiap penebangan mulai dari $4 \mathrm{~m}$ diwajibkan untuk menyisahkan 1 pohon induk. Hal ini dibuat agar regenerasi mangrove tetap berlangsung dengan asumsi pohon induk akan beregenerasi dan calon mangrove baru bisa tumbuh. Jika ada warga yang sewenang-wenang menebang mangrove, maka bisa dikenakan sanksi.yaitu :

a) Bagi pemilik lahan mangrove yang menebang mangrove tanpa menyisahkan pohon inti maka dikenakan sanksi berupa denda sebesar 2 kali lipat dari harga jual hasil penebangan tersebut.

b) Bagi yang menebang mangrove dilahan orang lain akan dikenakan sanksi berupa uang denda sebesar Rp. 100.000 perpohon dan ditanami kembali oleh warga yang mengambil mangrove sebanyak jumlah pohon yang ditebang.

b. Perilaku Antropsentrisme (Merusak)

Pemanfaatan hutan mangrove di Desa Balangdatu yang dilakukan masyarakat setempat cenderung merusak dan tidak lestari.Dimana hutan mangrove dijadikan komoditas utama untuk produksi arang, kayu bakar dan tiang/patok rumput laut.Hasil produksi ini umumnya dimanfaatkan untuk memenuhi kebutuhan masyarakat setempat.Kecuali produksi arang, konsumen utamanya adalah pemilik restoran-restoran dikota Makassar dan sekitanya.Hasil produksi arang ini tidak tetap tergantung dari musim dan permintaan. Penyebab utama kerusakan di hutan mangrove dilokasi penelitian karena ulah masyarakat. Kerusakan tersebut terdiri dari :

a) Alih fungsi lahan mangrove menjadi tambak. Tingginya keinganan masyarakat untuk mengkonversi mangrove menjadi tambak udang karena harga udang melambun tinggi. Alat berat didatangkan untuk mengkonversi hutan mangrove menjadi areal tambak udang. Budidaya tambak udang ketika itu menjadi lapangan ekonomi baru bagi masyarakat Desa Balangdatu. Sehingga, konversi hutan mangrove menjadi lahan tambak memberikan kontribusi yang sangat besar terhadap kerusakan dan penurunan luas hutan mangrove di desa Balangdatu.

b) Eksploitasi kayu mangrove.Eksploitasi yang berlebihan terhadap hutan mangrove yang dilakukan untuk keperluan kayu bakar dan arang, sebagai bahan baku arang, maupun yang diperuntukkan pemukiman yang pada akhirnya akan memberikan dampak negatif terhadap masyarakat.Aktivitas penebangan ini dilakukan karena adanya permintaan arang yang berasal dari Takalar dan Makassar dalam jumlah yang cukup besar, hingga kegiatan penebangan yang dilakukan untuk memenuhi kebutuhan keluarga masyarakat setempat

c) Pencemaran lingkungan. Banyak masyarakat membuang sampah plastik dan limbah rumah tangga disekitar hutan mangrove sehingga mengurangi kemampuan pertumbuhan akar mangrove dan pada akhirnya mati.

Timbulnya kerusakan tersebut erat kaitannya dengan akses masyarakat dalam memanfaatkan hutan mangrove. Akses harus dipahami dengan melihat bahwa kemampuan memperoleh keuntungan dipengaruhi oleh beragam hambatan yang ada baik itu ekonomi dan kultural tertentu disaat akses terhadap sumber daya tersebut di usahakan, sehingga ada relasi bagaimana teknologi, pasar, modal, dan kepemilikan yang dapat membentuk dan mempengaruhi akses.

a) Teknologi. Teknologi disini paling tidak mempengaruhi pada kemampuan daya dukung terhadap sumber daya alam. Beberapa sumber daya misalnya tidak dimanfaatkan tanpa teknologi sepeti pada 
pembuatan tambak, masyarakat mengkonversi hutan mangrove menjadi tambak dengan mnedatangkan alat-alat berat seperti excapator dan dozer.

b) Pasar. Dimana kemampuan seseorang atau kelompok untuk mendapatkan keuntungan ketika masuk kedalam proses pertukaran ekonomi, seperti halnya hutan mangrove bisa berubah ketika sebuah komoditi tanaman tertentu diminati masyarakat. Dimana masyarakat kemudian tidak terkendali membuka hutan saat tanaman tersebut laku di pasar, seperti arang.

c) Kepemilikan. Kepemilikan juga mempengaruhi kemampuan individu dalam mendapatkan keuntungan dari sebuah sumber daya alam. Akses ini menjadi hal penting bagi penduduk atau masyarakat untuk memperoleh suatu barang atau sumberdaya. Seperi kepemilikan hutan mangrove scara pribadi.

d) Modal. Modal memepunyai peranan penting dalam menentukan siapa yang mampu atau tidak mengakses sumberdaya alam. Modal mempengaruhi terjadinya produksi, konversi lahan, dan tenaga kerja dan berbagai proses yang mempengaruhi lingkungan secara fisik.

\section{2) Dampak Perilaku Masyarakat di Hutan Mangrove}

a) Dampak Positif Perilaku Masyarakat di Hutan Mangrove

Masyarakat di Desa Balangdatu sebagian besar telah menyadari bahwa banyaknya manfaat yang diperoleh dari keberadaan hutan mangrove. Dampak positif yang diperoleh masyarakat dari pelestarian hutan mangrove berpengaruh terhadap aspek ekologi, aspek biologi dan aspek ekonomi.Aspek ekologi, dimana terlindunginya pemukiman masyarakat dari hempasan gelombang air laut dan angin kencang karena tegakan mangrove yang rapat dan sistem perakaran yang kokoh sehingga hutan mangrove dapat mampu meredam gelombang. Aspek ekonomi, dimana kayu mangrove memiliki nilai ekonomi yang cukup tinggi, masyarakat biasanya memanfaatkan kayu mangrove sebagai kayu bakar dan produksi arang, selain itu pemanfaatan mangrove untuk obat-obatan, akar muda mangrove (akar yang belum menyentuh tanah) berkhasiat menyembuhkan sakit perut (diare) . Aspek biologi, dimana hutan mangrove ini dijadikn sebagai habitat dan tempat perkembangbiakan ikan, udang, kepiting yang dapat di konsumsi masyarakatdan diperjual belikan dipasar, jika kondisi cuaca yang snagat tidak mendukung untuk melaut, maka aktifitas masyarakat nelayan lebih banyak berpusat untuk mencari ikan di bawah tegakan mangrove.

b) Dampak Negatif Perilaku Masyarakat di Hutan Mangrove.

Dampak rusaknya hutan mangrove dilihat dari apa yang dirasakan oleh masyarakat yang beraktifitas langsung di sekitarnya..Dampak yang dirasakan masyarakat akibat rusaknya ekosositem mangrove yaitu abrasi pada pematang tambak dan pemukiman penduduk menimbulkan kerugian terhadap budidaya tambakudang akibat hantaman gelombang laut dan diwaktu pasang air lautmasuk dipemukiman penduduk sehingga menganggu aktifitas masyarakat.Kemudian, berkurangnya hasil tangkapan disebabkan berkurangnya ikan, kepiting dan udang karena habitatnya telah rusak. Kemudian terjadi intrusi air laut dimana masyarakat kesulitan mendapat air tawar karena air tanah telah terkontaminasi dengan air laut sehingga tidak baik untuk di konsumsi karena bisa menyebabkan keracunan.

\section{SIMPULAN DAN SARAN}

Kesimpulan penelitian adalah: (1) Bentuk perilaku masyarakat pesisir di hutan mangrove terdiri atas dua yaitu perilaku ekosentrisme (melestariakan) dimana perilaku ini muncul dalam tindakan pelestarian yang terdiri pelestarian berbasis masyarakat meliputi pembibitan, penanaman, pemeliharaan dan pengawasan hutan mangrove serta pelestarian dengan penerapan kearifan lokal dimana kearifan lokal ini mengstur tata cara penebangan hutan mangrove meskipun dilhan milik pribadi. Kemudian perilaku antroposentrisme (pengrusakan) dimana ekosistem hutan bakau memberikan kontribusi secara nyata bagi peningkatan pendapatan masyarakat sehingga mendorong masyarakat melakan tindak eksploitasi kayu mangrove, konversi lahan mangrove menjadi tambak dan pencemaran lingkungan; (2) Apapun yang dilakukan oleh masyarakat terhadap lingkungan hidupnya (merusak atau melestarikan alam) dampaknya akan kembali ke masyarakat. Keputusan masyarakat untuk merubah atau melestarikan hutan mangrove menimbulkan dampak postif 
dan negatif yang berpengaruh pada aspek fisik, aspek ekologi, dan aspek ekonomi yang berpengaruh pada kehidupan masyarakat.

Saran penelitian adalah: (1) Bagi masyarakat diharapkan untuk ikut berpartisipasi dalam menjaga dan melestarikan hutan mangrove agar masyarakat memperoleh manfaat baik aspek fisis, ekonomi dan ekologi; (2) Bagi pemerintah Desa Balangdatu dalam pelestarian hutan mangrove diharapkan agar mendorong anak sekolah sebagai pendidikan usia dini, agar supaya mereka menjadi generasi penerus dalam melestariakn hutan mangrove; (3) Perlu dukungan dari semua pihak agar masyarakat mau terlibat dan mengambil bagian dalam pengelolaan hutan mangrove dan turut mencegah terjadinya keruskan dihutan mangrove

\section{DAFTAR RUJUKAN}

Barlow Colin \& dkk. 2002. Manusia dan Lingkungan. Jakarta: Buku Antar Bangsa.

Damsar. 2015. Pengantar teori sosiologi. Jakarta: Pustaka Sinar Harapan

Dwi Susilo.M.A. 2014.Sosiologi lingkungan. Jakarta: PT Raja Grafindo Persada.

Gumilar Iwang.2018. Partisipasi Masyarakat Pesisir Dalam Pelestarian Ekosistem Hutan Mangrove (Studi Kasus di Kabupaten Indramayu Jawa Barat). Jurnal: Fakultas Perikanan dan Ilmu Kelautan Universitas Padjadjaran. Jurnal Ilmu-ilmu Sosial dan Humaniora Vol 20 No.2. (Diakses 20 Agustus2018)
Hardhani, 2002. Faktor-faktor yang Mempengaruhi Peran Serta Masyarakat Dalam Pengelolaan Hutan Mangrove di Kecamatan Pulau Laut Utara Kabupaten Kota Batu Kalimantan Selatan. Tesis. Semarang : Program Pascasarjana Unisversitas Ponerogo.

Hermawan Arman.2018. Kearifan Lokal Masyarakat Pulau Tanakeke Dalam Mengelola Ekosistem Mangrove. Jurnal : Balai Litbang Lingkungan Hidup dan Kehutanan MakassarVol. 15 No. 1 (http://balithutmakassar.org/wpcontent/uploads/2018/07/05_Kearif an-Lokal-

Tanakeke Arman InfotekEbony.pdf. Diakses tanggal 14 November 2019)

Mustaqim. 2016. Paradigma Perilaku Sosial Dengan Pendekatan Behavioristik. Jurnal Studi Islam dan Sosial vol.no.2. Fakultas Tarbiyah Institut Agama Islam (IAI) Ngawi.

Pramudji, 2000. Dampak Perilaku Manusia Pada Ekosistem Hutan Mangrove di Indonesia. Jurnal Vol XXV, No. 2 (file://D:/contoh\%20tesis/Documentas i/oseana_xxv(2)13-20.pdf,diakses pada tanggal 25 Januari 2020).

Ribot, Jesse C. and Nancy Lee Peluso. 2003, A Theory Of Access, Rural Sociology, Vol.68, No.2, June, Rural Sociologi Society, (Jurnal diakses pada tanggal 16 Agustus 2019) 